\title{
Incidence of bla genes among uropathogenic Escherichia coli isolates from HIV and non-HIV patients in South India
}

\author{
Kesavaram Padmavathy ${ }^{1,2^{*}}$, Padma Krishnan', Sikhamani Rajasekaran ${ }^{3}$ \\ From First International Science Symposium on HIV and Infectious Diseases (HIV SCIENCE 2012) \\ Chennai, India. 20-22 January 2012
}

\section{Background}

Group 3a/b cephalosporins are currently being used in the treatment of UTI and urosepsis. However, Extended Spectrum Beta-Lactamase (ESBL) mediated resistance has been increasingly reported among uropathogens from HIV patients. We sought to determine the incidence of ESBL genes- $b l a_{C T X-\mathrm{M}}, b l a_{T E M}$ and $b l a_{S H V}$ among E. coli isolates from HIV (with increased exposure to cephalosporins) and non-HIV antenatal patients.

\section{Methods}

PCR detection of $b l a_{C T X-M}, b l a_{T E M}$ and $b l a_{S H V}$ were carried out among ESBL producing urinary $E$. coli isolates from HIV $(n=57)$ and non-HIV antenatal patients $(n=22)$. Fisher's exact test was employed to analyze the statistical significance of the results.

\section{Results}

Overall, $31.7 \%, 59.5 \%$ of the E. coli isolates carried bla$T E M, b l a_{C T X-M}$ respectively, while none harboured bla $_{\mathrm{SHV}}$. When stratified based on host group, significant difference was observed in the incidence of $b l a_{C T X-M}$ among the isolates from HIV and non-HIV patients (70.2\% vs $31.8 \%$ respectively, $\mathrm{p}=0.0024$; OR 5.042; $95 \%$ $\mathrm{CI}=1.7441-14.5759)$. Nonetheless, difference in prevalence of bla $a_{T E M}$ among the HIV and non-HIV isolates was not statistically significant $(29.8 \%$ vs $36.4 \%$, p $=$ 0.5979). Co-occurrence of bla $a_{T E M}$ and $b l a_{C T X-M}$ was detected among $22.8 \%, 0 \%$ of the $E$. coli isolates from HIV and non-HIV patients respectively (OR 5.1447; 95\% $\mathrm{CI}=1.3766-19.2273)$.

\footnotetext{
* Correspondence: padmabakianath@yahoo.co.in

'Dept of Microbiology, Dr. ALM PGIBMS, University of Madras, Chennai, India Full list of author information is available at the end of the article
}

\section{Conclusion}

Our results augment the fact that frequent exposure to cephalosporins serves as the driving selection force leading to increased incidence of ESBL $\left(b l a_{C T X-M}\right)$ mediated resistance among the $E$. coli isolates from HIV patients. Hence, the risk associated with antimicrobial exposure needs to be considered in therapeutic decision making.

\section{Author details \\ 'Dept of Microbiology, Dr. ALM PGIBMS, University of Madras, Chennai, India. ${ }^{2}$ Sree Balaji Dental College and Hospital, Chennai, India. ${ }^{3}$ Government Hospital of Thoracic Medicine, Chennai, India.}

Published: 4 May 2012

doi:10.1186/1471-2334-12-S1-P21

Cite this article as: Padmavathy et al:: Incidence of bla genes among uropathogenic Escherichia coli isolates from HIV and non-HIV patients in South India. BMC Infectious Diseases 2012 12(Suppl 1):P21.

Submit your next manuscript to BioMed Central and take full advantage of:

- Convenient online submission

- Thorough peer review

- No space constraints or color figure charges

- Immediate publication on acceptance

- Inclusion in PubMed, CAS, Scopus and Google Scholar

- Research which is freely available for redistribution 